\title{
Comparative expression analysis of the renin-angiotensin system components between white and brown perivascular adipose tissue
}

\author{
B Gálvez-Prieto*, J Bolbrinker ${ }^{1, *}$, P Stucchi, A I de las Heras, B Merino², S Arribas ${ }^{3}$, M Ruiz-Gayo², \\ M Huber ${ }^{1}$, M Wehland ${ }^{1}$, $R$ Kreutz ${ }^{1,4}$ and $\mathbf{M}$ S Fernandez-Alfonso \\ Unidad de Cartografía Cerebral, Instituto Pluridisciplinar, Universidad Complutense, Juan XXIII, 1, 28040 Madrid, Spain \\ ${ }^{1}$ Institute of Clinical Pharmacology and Toxicology, Charité Centrum für Thearapieforschung, Charité-Universitätsmedizin Berlin, 12200 Berlin, Germany \\ ${ }^{2}$ Departamento de Farmacología, Tecnología y Desarrollo Farmacéutico, Facultad de Farmacia, Universidad CEU-San Pablo, 28668 Madrid, Spain \\ ${ }^{3}$ Departamento de Fisiología, Facultad de Medicina, Universidad Autónoma de Madrid, 28010 Madrid, Spain \\ ${ }^{4}$ Department of Medicine, Outpatient Clinic, Charité Centrum für Innere Medizin und Dermatologie, Charité-Universitätsmedizin Berlin, \\ 12200 Berlin, Germany \\ (Correspondence should be addressed to M S Fernández-Alfonso; Email: marisolf@farm.ucm.es) \\ *(B Gálvez-Prieto and J Bolbrinker contributed equally to this work)
}

\begin{abstract}
Recent studies have demonstrated that the rat adipose tissue expresses some of the components necessary for the production of angiotensin II (Ang II) and the receptors mediating its actions. The aim of this work is to characterize the expression of the renin-angiotensin system (RAS) components in perivascular adipose tissue and to assess differences in the expression pattern depending on the vascular bed and type of adipose tissue. We analyzed Ang I and Ang II levels as well as mRNA levels of RAS components by a quantitative RT-PCR method in periaortic (PAT) and mesenteric adipose tissue (MAT) of 3-month-old male Wistar-Kyoto rats. PAT was identified as brown adipose tissue expressing uncoupling protein-1 (UCP-1). It had smaller adipocytes than those from MAT, which was identified as white adipose tissue. All RAS components,
\end{abstract}

except renin, were detected in both PAT and MAT. Levels of expression of angiotensinogen, Ang-converting enzyme (ACE), and ACE2 were similar between PAT and MAT. Renin receptor expression was five times higher, whereas expression of chymase, $\mathrm{AT}_{1 \mathrm{a}}$, and $\mathrm{AT}_{2}$ receptors were significantly lower in PAT compared with MAT respectively. In addition, three isoforms of the $\mathrm{AT}_{1 \mathrm{a}}$ receptor were found in perivascular adipose tissue. The $\mathrm{AT}_{1 \mathrm{~b}}$ receptor was found at very a low expression level. Ang II levels were higher in MAT with no differences between tissues in Ang I. The results show that the RAS is differentially expressed in white and brown perivascular adipose tissues implicating a different role for the system depending on the vascular bed and the type of adipose tissue.

Journal of Endocrinology (2008) 197, 55-64

\section{Introduction}

The renin-angiotensin system (RAS) plays a central role in blood pressure regulation by modulating vascular tone, vascular structure and renal function. The substrate of the system, angiotensinogen, is cleaved by renin, producing angiotensin I (Ang I), which is then converted to Ang II by either Ang-converting enzyme (ACE) and/or chymase. The decapeptide Ang I is also a substrate of ACE2, which catalyzes Ang 1-7 production. Ang II is considered to be the major effector peptide of the RAS by binding two different receptors, $\mathrm{AT}_{1}$ and $\mathrm{AT}_{2}$. The $\mathrm{AT}_{1}$ receptors are widely distributed and mediate most of the biological responses that contribute to the known pressor, trophic, and pro-inflammatory effects of Ang II, whereas the $\mathrm{AT}_{2}$ receptors antagonize several of the $\mathrm{AT}_{1}$ receptor-mediated responses (for review see Paul et al. (2006)). In rodents, the existence of two $\mathrm{AT}_{1}$ receptor isoforms, $\mathrm{AT}_{1 \mathrm{a}}$ and $\mathrm{AT}_{1 \mathrm{~b}}$, has already been described (Iwai \& Inagami 1992).

During the last decade, the existence of a local RAS in adipose tissue and its functional importance has attracted closer attention (Gorzelniak et al. 2002, Engeli et al. 2003, Paul et al. 2006). The white adipose tissue (WAT) is the most abundant source of angiotensinogen after the liver (Phillips et al. 1993). Moreover, almost all components of the system have been described in both white and brown adipose tissues (BAT; Cassis et al. 1988a, Engeli et al. 1999, Paul et al. 2006). From a functional point of view, adipose Ang II has been implicated in adipocyte homeostasis regulating growth, differentiation, and metabolism (Darimont et al. 1994, Harp \& DiGirolamo 1995, Saint-Marc et al. 2001, Janke et al. 2002). Furthermore, a pathophysiological relevance of Ang II 
production in the adipose tissue for blood pressure regulation cannot be excluded (Massiera et al. 2001, Engeli et al. 2003). Thus, an increased local formation of angiotensinogen and Ang II in rat adipocytes due to overfeeding might represent a link between increased adipose tissue mass and hypertension in rodents (Frederich et al. 1992, Boustany et al. 2004). Similarly, local Ang II formation in adipose tissue is increased in obese hypertensive subjects (Giacchetti et al. 2002, Gorzelniak et al. 2002).

While most of the studies investigating the RAS in adipose tissue have focused on subcutaneous and visceral adipose tissues, little attention has been paid to perivascular fat. The latter tissue surrounds almost all blood vessels in different amounts. We and others have recently demonstrated the paracrine role of perivascular adipose tissue (PVAT) in the regulation of vasomotor function (Soltis \& Cassis 1991) due to the synthesis and release of several vasoactive factors, such as the adipocyte-derived relaxing factor (Löhn et al. 2002, Dubrovska et al. 2004, Verlohren et al. 2004, Galvez et al. 2006), leptin (Galvez et al. 2006), and superoxide anions (Gao et al. 2006). The aim of this work is to characterize the expression of the RAS in two types of PVAT, i.e. mesenteric (MAT) and periaortic adipose tissues (PAT), and to assess whether the system is differentially expressed depending on the vascular bed and type of adipose tissue.

\section{Materials and Methods}

\section{Animals}

Experiments were conducted in 3-month-old male WistarKyoto (WKY, $n=6$, 250-300 g; Charles River, Barcelona, Spain) maintained under controlled light (12-h light cycles from 0800 to $2000 \mathrm{~h}$ ) and temperature $\left(22-24^{\circ} \mathrm{C}\right)$ conditions. The rats were fed a normal rat chow (A.04, Panlab, Barcelona, Spain) and had free access to tap water. Animals were killed by decapitation and the MAT and PAT were rapidly removed. The Institutional Animal Care and Use Committee approved all experimental procedures according to the guidelines for ethical care of experimental animals of the European Community, as well as the Guide for the Care and Use of Laboratory Animals published by the US National Institutes of Health (NIH Publication No. 85-23, revised 1996).

\section{Isolation of adipocytes}

Adipocytes were prepared from MAT and PAT according to the method of Rodbell (1964) with minor modifications. Briefly, adipose tissue was cut into small pieces and digested with collagenase A $(1 \mathrm{mg} / \mathrm{ml})$ in Krebs-Ringer bicarbonate (KRB) buffer ( $\mathrm{pH} 7 \cdot 4)$ containing $4 \%(\mathrm{w} / \mathrm{v})$ BSA (fatty acid free, fraction V) and $5.5 \mathrm{mmol} / \mathrm{l}$ glucose at $37^{\circ} \mathrm{C}$ in a $\mathrm{O}_{2} /$ $\mathrm{CO}_{2}$ (19:1) atmosphere with continuous vigorous shaking (60 cycles/min). Subsequently, fat cells were dispersed and filtered through a silk screen, washed thrice with KRB buffer to eliminate collagenase, and resuspended in the same buffer. The size of the fat cells were measured by direct microscopic determination, and the mean adipocyte diameter was calculated from measurements of 100 cells.

\section{Histological study by confocal microscopy}

Sections of aortae and intact mesenteric resistance arteries with adherent PVAT were washed in PSS and mounted between a slide (provided with a well to avoid vessel compression) and a cover glass. The tissue was visualized with a Leica TCS SP2 confocal system (Leica Microsystems, Wetzlar, Germany) fitted with Argon and Helio-Neon laser sources and coupled to a Leica DMIRE 2 microscope, using the $488 / 515 \mathrm{~nm}$ line of the microscope as adipocytes exhibited autofluorescence at his wavelength. Adipocytes were localized and of serial optical sections ( $1 \mu \mathrm{m}$ thick) were captured from several areas with $20 \times$ oil objective for MAT and with $20 \times$ objective zoom 3 for PAT. Quantification of adipocyte diameter was obtained with Metamorph image analysis software (Universal Imaging Co., West Chester, UK).

\section{Western blot for UCP-1}

UCP-1 was measured in PAT and MAT. BAT was used as positive control. Briefly, the tissues were homogenized in ice-cold buffer containing $0.42 \mathrm{M} \mathrm{NaCl}, 20 \mathrm{mM}$ HEPES (pH 7·9), $1 \mathrm{mM} \mathrm{Na}_{4} \mathrm{P}_{2} \mathrm{O}_{7}, 1 \mathrm{mM}$ EDTA, $1 \mathrm{mM}$ EGTA, $1 \mathrm{mM}$ dithiothreitol, 20\% glycerol, $1 \mu \mathrm{g} / \mathrm{ml}$ aprotinin, $1 \mu \mathrm{g} / \mathrm{ml}$ leupeptin, $20 \mathrm{mM}$ sodium fluoride, $1 \mathrm{mM}$ trisodium orthovanadate, and $2 \mathrm{mM}$ phenylmethylsulfonyl fluoride. After 20 min ice-cold incubation, homogenates were centrifuged for $10 \mathrm{~min}$ and the pellet was discarded. Equivalent amounts of proteins $(50 \mu \mathrm{g})$ present in the supernatant were loaded in Laemmi buffer (50 mM Tris ( $\mathrm{pH} 6 \cdot 8$ ), 10\% SDS, $10 \%$ glycerol, $5 \%$ mercaptoethanol, and $2 \mathrm{mg} / \mathrm{ml}$ blue bromophenol) and size separated in 15\% SDS-PAGE. Proteins were transferred to polyvinylidene difluoride (PVDF) membranes (Amersham Pharmacia) using a transblot apparatus (BioRad). For immunoblotting, membranes were blocked with $5 \%$ nonfat dried milk in Tween-PBS (TPBS) for $1 \mathrm{~h}$. Primary antibodies against UCP-1 (Affinity BioReagent, Golden, CO, USA) were applied at a dilution of 1:1000 overnight at $4{ }^{\circ} \mathrm{C}$. After washing, appropriate secondary antibodies (antirabbit IgG-HRP conjugated, Amersham Bioscience) were applied for $1 \mathrm{~h}$ at a dilution of 1:2000. Blots were washed, incubated in commercial enhanced chemiluminescence reagents (Amersham Bioscence), and exposed to autoradiographic film. To prove equal loadings of samples, blots were re-incubated with $\beta$-actin antibody (Sigma) and secondary antibody (antimouse IgG-HRP conjugated, 1:4000, Amersham Bioscience). Films were scanned using a GS-800 Calibrated Densitometer (Bio-Rad) and blots were quantified using Quantity One software (Bio-Rad). The values were normalized by $\beta$-actin to account for variations in gel loading. 


\section{RNA isolation}

Total RNA of adipose tissue was isolated using RNeasy lipid tissue mini kit (Qiagen) according to the manufacturer's protocol. An on-column DNase digestion step was included in the protocol with RNase-free DNase set (Qiagen) to minimize genomic contamination. Concentration and purity of isolated RNA was determined by measuring the extinction at 260 and $280 \mathrm{~nm}$.

\section{Reverse transcription $(R T)$ and quantitative real-time PCR}

One microgram of total RNA was reverse transcribed in $40 \mu \mathrm{l}$ final volume using First Strand cDNA synthesis kit (Fermentas GmbH, St Leon-Rot, Germany) according to the manufacturer's instructions. Transcribed cDNA was stored at $-20^{\circ} \mathrm{C}$ until further use.

To quantify expression levels of genes of interest, we employed the real-time quantitative RT ('TaqMan') PCR as previously described (Bolbrinker et al. 2006). Briefly, the ABI PRISM 7000 SDS instrument in conjunction with the ABI TaqMan Universal Master Mix (Applied Biosystems, Darmstadt, Germany) was used to perform the assays with a final concentration of $300 \mathrm{nM}$ for the primers and $100 \mathrm{nM}$ for the probes. Fluorogenic probes and primers were synthesized by TIB Molbiol (Berlin, Germany). For details of primer and probe sequences, see Table 1 . Where no sequence for the probe is given either a SYBR Green dye-based assay was used for quantification according to the manufacturer's protocol (TAQurate GREEN Real-Time PCR MasterMix, Epicentre Biotechnologies, Madison, WI, USA) or no quantification was performed. To avoid signals of genomic origin, intronspanning primers were used and primers were checked for genomic signal before use. Specificity of the product was confirmed by sequencing.

Relative quantification was done using the standard curve method. Every sample was measured in triplicate. To normalize our expression data, we used $18 \mathrm{~S}$ as a housekeeping gene as previously described (Wendt et al. 2007), as well as hypoxanthine-guanine phosphoribosyltransferase (HPRT).

\section{Determination of Ang I and Ang II levels by HPLC}

Ten milligrams of adipose tissue were homogenized in $100 \mu \mathrm{l}$ Tris $(50 \mathrm{mmol} / \mathrm{l}, \mathrm{pH} 7 \cdot 4), 0.1 \mathrm{mmol} / 1 \mathrm{EDTA}$, and $1 \mathrm{mg} / \mathrm{ml}$ bacitracin. After centrifugation at $19000 \mathrm{~g}$ for $10 \mathrm{~min}, 50 \mu \mathrm{l}$ supernatant were loaded on a Kromasil C8 column $(0 \cdot 4 \times$ $20 \mathrm{~cm}$ ) and eluted by means of a linear gradient from 26 to $70 \%$ acetonitrile/water containing $0 \cdot 05 \%$ trifluoroacetic acid. Fractions containing Ang I and Ang II were collected, then concentrated in a speed-vacuum system and resuspended in $50 \mu \mathrm{l}$ Tris $(50 \mathrm{mmol} / \mathrm{l}, \mathrm{pH} 7 \cdot 4)$. Ang I and Ang II were quantified using specific EIA kits for rat Ang I and Ang II respectively (Phoenix, Europe, Karlsruhe, Germany).

\section{Statistical analysis}

All values are given as mean \pm S.E.M. Student's $t$-tests or ANOVA were used as appropriate. A value of $P<0.05$ was considered statistically significant; $n$ represents the number of samples.

\section{Results}

\section{Characterization of perivascular adipocytes}

Figure 1 shows adipose tissues surrounding the mesenteric artery (Fig. 1a-c) and the aorta (Fig. 1d-f). Perivascular adipocytes from MAT were larger in size (mean diameter= $40 \cdot 2 \pm 3 \mu \mathrm{m}$; Fig. $1 \mathrm{~b}$ and c) compared with adipocytes obtained from PAT, which had smaller diameters (mean diameter $=9 \cdot 4 \pm 0 \cdot 2$; Fig. 1 e and f). The complete distribution of the cell sizes, as well as the analysis and comparison of the distributions by curve fitting of mesenteric adipocytes has been previously published by our group (Gálvez et al. 2006).

In order to determine the type of adipose tissue (i.e. WAT, or BAT), expression of UCP-1, a specific marker for BAT, was determined. Figure 2 shows that PAT is positive for UCP-1. The level of UCP-1 expression was similar to that of BAT used as positive control, thus suggesting that PAT is brown. MAT only showed a low expression of UCP-1, suggesting that it is WAT.

\section{$m R N A$ expression analysis of $R A S$ components}

We first performed qualitative expression analysis of the RAS components. This analysis revealed that angiotensinogen, ACE, ACE2, and chymase, as well as (pro)renin, $\mathrm{AT}_{1 \mathrm{a}}$, and $\mathrm{AT}_{2}$ receptors are expressed in both PAT and MAT, while renin expression could not be detected. Expression levels of the $\mathrm{AT}_{1 \mathrm{~b}}$ receptor in PAT and MAT were very low, and therefore no further quantification analysis was performed (Fig. 4a).

\section{Angiotensinogen}

Angiotensinogen expression was detected in PVAT and was similar between PAT and MAT (Fig. 3a; Angiotensinogen/ HPRT: $100 \% \pm 26 \%$ vs $143 \% \pm 22 \%, P=0 \cdot 27)$.

\section{(Pro)renin receptor}

(Pro)renin receptor levels were approximately fivefold lower in MAT than in PAT $(P=0.0059$; Fig. 3b; (pro)renin receptor/HPRT: $100 \% \pm 15 \%$ vs $14 \% \pm 0 \cdot 4 \%, P=0 \cdot 003$ ). To our knowledge, this is the first study reporting renin receptor expression in BAT. 
Table 1 Real-time quantitative RT-PCR: primers and probes

\section{Angiotensinogen}

Renin receptor

Renin

ACE

ACE2

\section{Chymase}

$\mathrm{AT}_{1 \mathrm{a}}($ exon $1+3)$

$\mathrm{AT}_{1 \mathrm{a}}($ exon $1+2+6 \mathrm{bp}+3)$

$\mathrm{AT}_{1 \mathrm{~b}}$

$\mathrm{AT}_{2}$

$18 \mathrm{~S}$

HPRT

\section{Gene symbol/ensembl gene ID}

Agt/ENSRNOG00000018445

Atp6ap2/ENSRNOG00000003858

Ren1/ENSRNOG00000002937

Ace/ENSRNOG00000007467

Ace2/ENSRNOG00000003911

Cma1/ENSRNOG00000020563

Agtr1a/ENSRNOG00000018346

Agtr1b/ENSRNOG00000010640

Agtr2/none

Rnr1/none

Hprt/ENSRNOG00000031367
Forward $(F)$, reverse $(R)$

$$
\begin{aligned}
& \text { F: CTACGTTCACTTCCAAGGGAAGA } \\
& \text { R: CACAGACACTGAGGTGCTGTTG } \\
& \text { F: CATCCCTGGTGAGGAAGTCAAG } \\
& \text { R: CGCAAGGTTGTAGGGACTTTG } \\
& \text { F: GGTGCCCTCCACCAAGTGT } \\
& \text { R: GCTAGAGGATTCCGAGGAGTCA } \\
& \text { F: TTGTCTGTCACTGGAGCCTGA } \\
& \text { R: CCACACCCAAAGCAATTCTTC } \\
& \text { F: GAGGAGAATGCCCAAAAGATGA } \\
& \text { R: GAAATTTTGGGCGATCTTGGA } \\
& \text { F: GGCAGAAGCTCGAGGTTGAA } \\
& \text { R: GCCTAGGGTTAGCTTGGCTTTC } \\
& \text { F: CACATTCCCTGTCAAGTGGATTT } \\
& \text { R: CATTTTGTTTTTCTGGGTTGAGTTG } \\
& \text { F: CCACATTCCCTGAGTTAACATATGA } \\
& \text { R: GAGTTGGTCTCAGACACTATTCGAAA } \\
& \text { F: ACCAGACCAGACACACACACCTT } \\
& \text { R: TCTTGGATTCTTTTAATTCCATCTTCA } \\
& \text { F: CCTTCCTGTATTGTTTCGTTGGA } \\
& \text { R: TGGAGCCAAGTAATGGGAACTC } \\
& \text { F: GGAGCCTGCGGCTTAATTT } \\
& \text { R: CAACTAAGAACGGCCATGCA } \\
& \text { F: CTCATGGACTGATTATGGACAGGACT } \\
& \text { R: TCCAGCAGGTCAGCAAAGAAC }
\end{aligned}
$$

Probe

CCAGAACTCATGGAGCCCAGTCAGCT

CATCCTTGAGACGAAACA

TCСССТСТACACTGCСTGTGAGATTCACA

TGACAAATATAATGGCCACGTCCCGGT

CTGCGGCCAAATGGTCTGCCTT

CATTCATCCAAACTATC

NA

ATCACCAGGTAAAGGTC

NA

CCGCTTCCAACAGAAGCTCCGTAGTG

CAATCTGTCAATCCTGTCCGTGTCCG

NA

Forward (F) and reverse primers (R) (5'-3') for PCR amplification and fluorogenic probes ( $5^{\prime}$ FAM - $3^{\prime}$ TAMRA) are given for the analysis of quantitative real-time PCR; NA, not applicable as SYBR green-based assay was used for detection ( $\mathrm{AT}_{1 \mathrm{a}}$ (exon $\left.1+3\right)$, $\mathrm{HPRT}$ ) or no quantification was performed $\left(\mathrm{AT}_{1 \mathrm{~b}}\right)$. 
Mesenteric perivascular adipose tissue
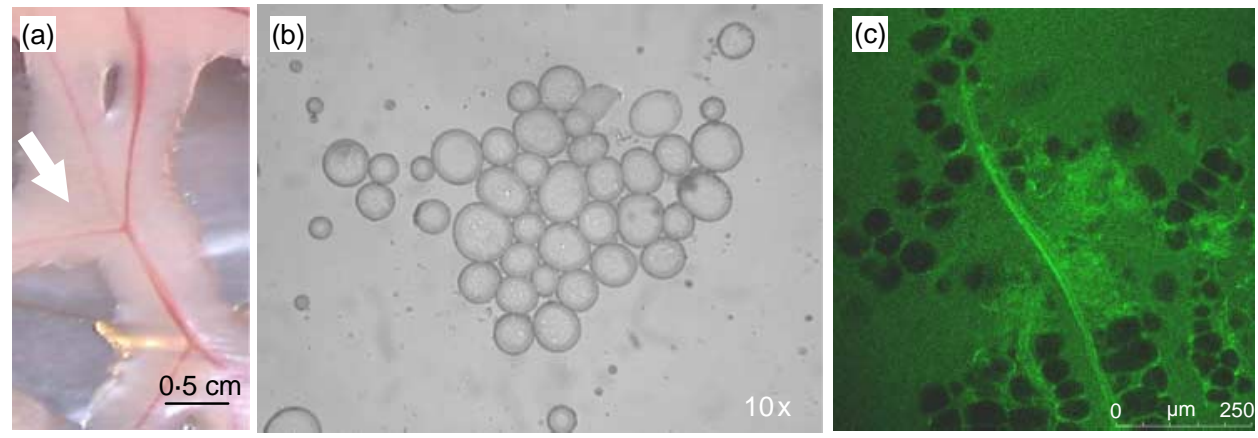

Periaortic adipose tissue
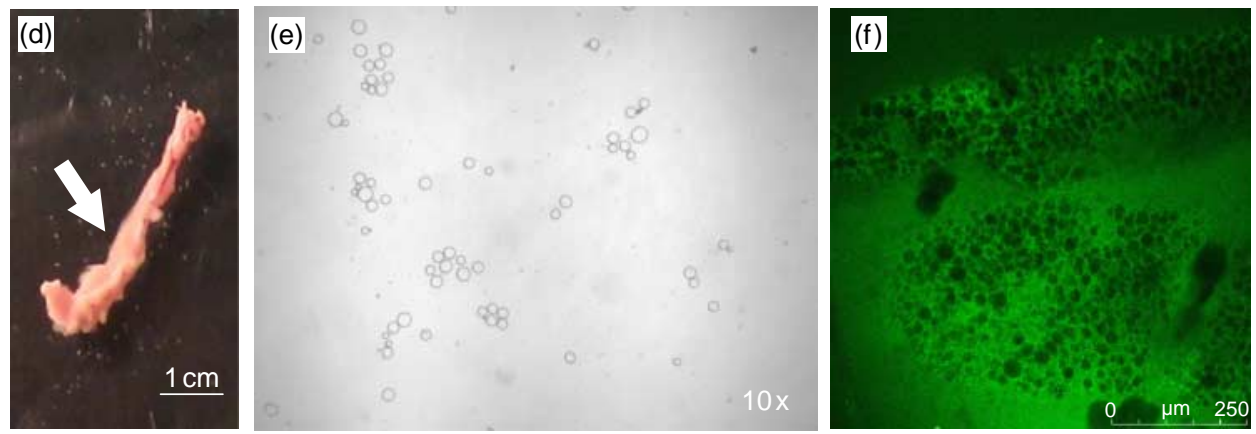

Figure 1 MAT and PAT of Wistar-Kyoto rats. Upper panel: (a) mesenteric artery surrounded by adipose tissue (arrow), (b) adipocytes isolated from fresh MAT (magnification 10×), and (c) adipocytes in a whole section of MAT observed by confocal microscopy. Lower panel: (d) aorta surrounded by adipose tissue (arrow),

(e) adipocytes isolated from fresh PAT (magnification $10 \times$ ), and ( $\mathrm{f}$ ) adipocytes in whole section of PAT observed by confocal microscopy. Full colour version of this figure available via http://dx.doi.org/10.1677/JOE-07-0284

ACE, ACE2, and chymase

Expression levels of ACE showed a trend for higher expression levels in MAT as observed by normalization with 18S (Fig. 3c), which was significant when normalizing data with HPRT $(100 \% \pm 14 \%$ vs $195 \% \pm 25 \%, P=0 \cdot 018)$. ACE2 levels (Fig. 3d) were similar between PAT and MAT (ACE2/ HPRT: $100 \% \pm 27 \%$ vs $148 \% \pm 19 \%, P=0 \cdot 220)$. By contrast, chymase expression was almost sevenfold higher in MAT compared with PAT $(P=0 \cdot 0013$; Fig. 3e; chymase/HPRT: $100 \% \pm 15 \%$ vs $627 \% \pm 54 \%, P<0 \cdot 001)$.

\section{Angiotensin receptors}

The $\mathrm{AT}_{2}$ receptor expression was significantly higher in MAT than in $\operatorname{PAT}\left(P<0 \cdot 0001 ;\right.$ Fig. $3 f ; \mathrm{AT}_{2}$ receptor/HPRT: $100 \% \pm 26 \%$ vs $790 \% \pm 111 \%, P=0 \cdot 006)$.

While generating the standard curve for quantification of $\mathrm{AT}_{1 \mathrm{a}}$ receptor, we detected three different bands in RT-PCR indicating the existence of three splice variants of the receptor in adipose tissue (Fig. 4b). Sequencing revealed specificity of all three products. The lowest band representing the shortest amplicon comprises $\mathrm{AT}_{1 \mathrm{a}}$ lacking exon 2 (exon $1+3$ ).
The band in the middle with a size of about $300 \mathrm{bp}$ represents the wild-type form after normal splicing (exon $1+2+3$ ). The analysis of the amplicon represented by the band above revealed an insertion of $6 \mathrm{bp}$ derived from intronic sequence (exon $1+2+6 b p+3)$. For quantification of the shortest and the longest isoform, two specific assays were designed (Table 1). Expression of the $\mathrm{AT}_{1 \mathrm{a}}$ exon $1+3$ was similar between PAT and MAT (Fig. 4c; $\mathrm{AT}_{1 \mathrm{a}}$ receptor (exon 1+3)/ HPRT: $100 \% \pm 39 \%$ vs $142 \% \pm 9 \%, P=0 \cdot 381)$, whereas expression of the longest amplicon with exon $1+2+6 \mathrm{bp}+3$ was significantly higher in MAT compared with PAT $\left(P<0 \cdot 0001\right.$; Fig. $4 \mathrm{~d}_{\mathrm{AT}_{1 \mathrm{a}}}$ receptor/HPRT: $100 \% \pm 13 \%$ vs $482 \% \pm 40 \%, P<0 \cdot 001)$.

\section{Ang I and Ang II peptide levels}

In order to assess the functionality of the RAS in PVAT and to validate the RT-PCR expression analysis, we determined levels of Ang I and Ang II peptides in these tissues. Ang I and Ang II were detected in both PAT and MAT. There were no significant differences in the amount of Ang I between the adipose tissues (Fig. 5a). However, Ang II protein level was significantly higher in MAT than in PAT $(P=0 \cdot 043$; Fig. $5 b)$. 

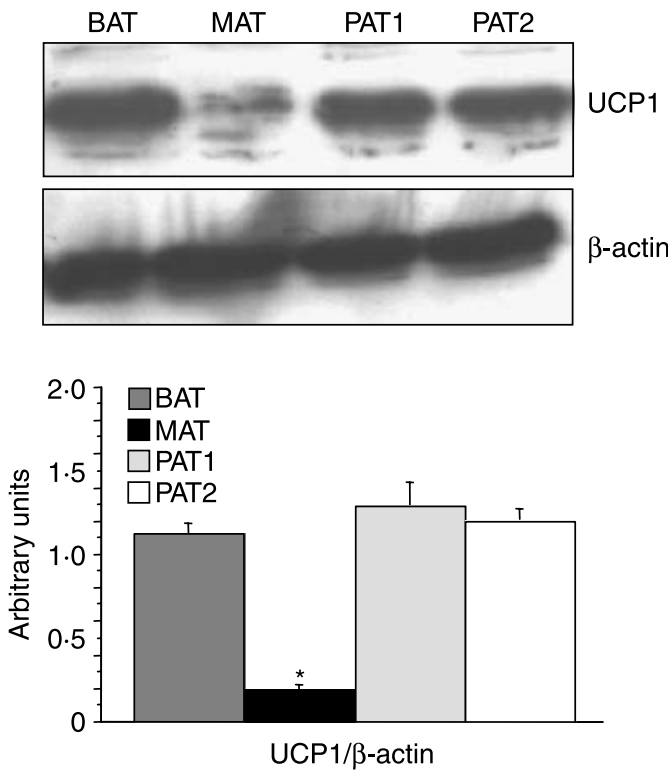

Figure 2 Immunoblots of UCP-1 obtained from interscapular brown adipose tissue (BAT), mesenteric adipose tissue (MAT), and periaortic adipose tissue (PAT). Bottom panel summarizes the level of UCP-1 expression normalized by $\beta$-actin as mean \pm s.E.M. Values correspond to three individual values. ${ }^{*} P<0 \cdot 05$ compared with values obtained from BAT.

\section{Discussion}

In this study, we show expression of all components of the RAS, except renin, in perivascular adipose tissue of the aorta and mesenteric arteries from WKY rats. An important new finding is the expression of the (pro)renin receptor, ACE2 and of three $\mathrm{AT}_{1 \mathrm{a}}$ receptor isoforms in perivascular adipose tissue. Gene expression levels of some RAS components are different between periaortic (BAT) and perimesenteric fat (WAT). The finding that Ang II levels and both $\mathrm{AT}_{1 \mathrm{a}}$ and $\mathrm{AT}_{2}$ receptor expression levels are higher in mesenteric fat suggests that RAS-mediated effects might differ depending on the type of surrounding adipose tissue and the type of vascular bed.

Adipose tissue and adipocytes contain most of the components of the RAS giving rise to local Ang II synthesis at the tissue level (Saye et al. 1993, Harp \& DiGirolamo 1995, Crandall et al. 1999, Engeli et al. 1999, 2000, Schling et al. 1999). Previously, the vast majority of studies investigating the expression of RAS components in adipose tissue have been performed in subcutaneous and visceral fat mainly obtained from epididymal and retroperitoneal tissues respectively. So far, no study has assessed the presence of the RAS in perivascular adipose tissue. Whether perivascular adipose tissue can be considered as visceral adipose tissue or not, is a matter of definition. According to Märin et al. (1992), visceral (or intraperitoneal) fat is mainly composed of omental, mesenteric, and retroperitoneal fat masses. In view of this definition, adipose (a)

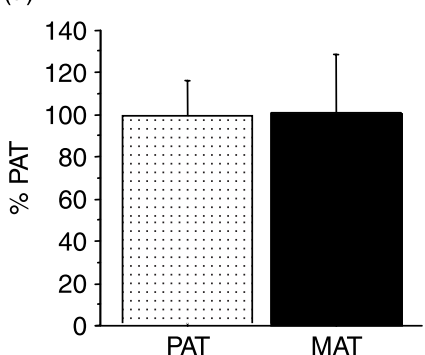

(d)

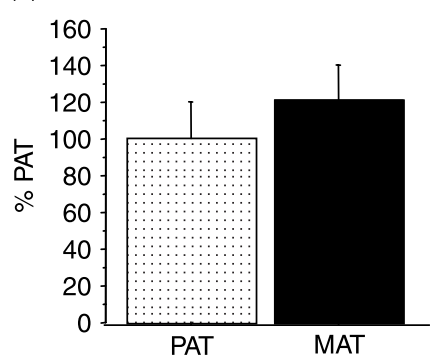

(b)

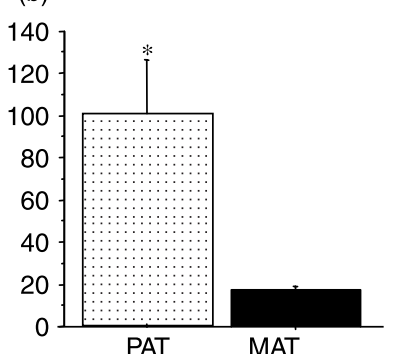

Chymase

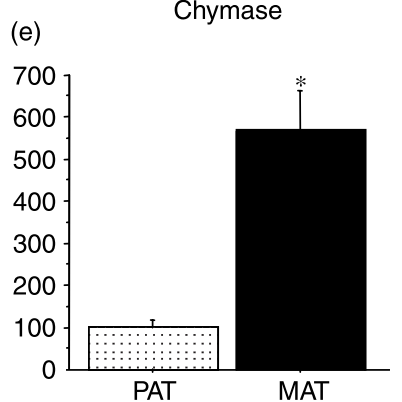

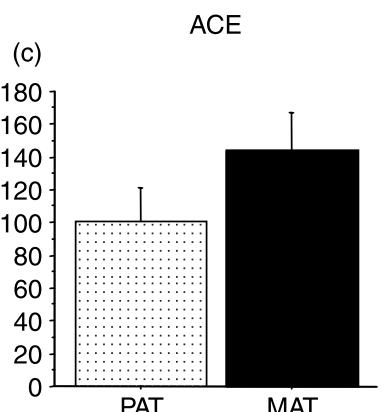

$\mathrm{AT}_{2}$ receptor

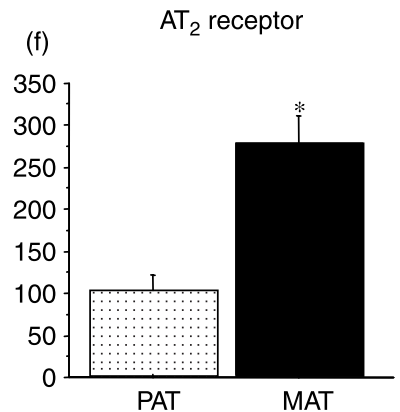

Figure 3 mRNA expression of RAS components in perivascular adipose tissues: periaortic adipose tissue (PAT) and mesenteric adipose tissue (MAT). (a) Angiotensinogen, (b) (pro)renin receptor, (c) ACE, (d) ACE2, (e) chymase, and (f) $\mathrm{AT}_{2}$ receptor. All results are normalized to the housekeeping gene $18 \mathrm{~S}$ and are expressed as percentage of the expression level in PAT. $n=6$ for each group. ${ }^{*} P<0 \cdot 05$. 

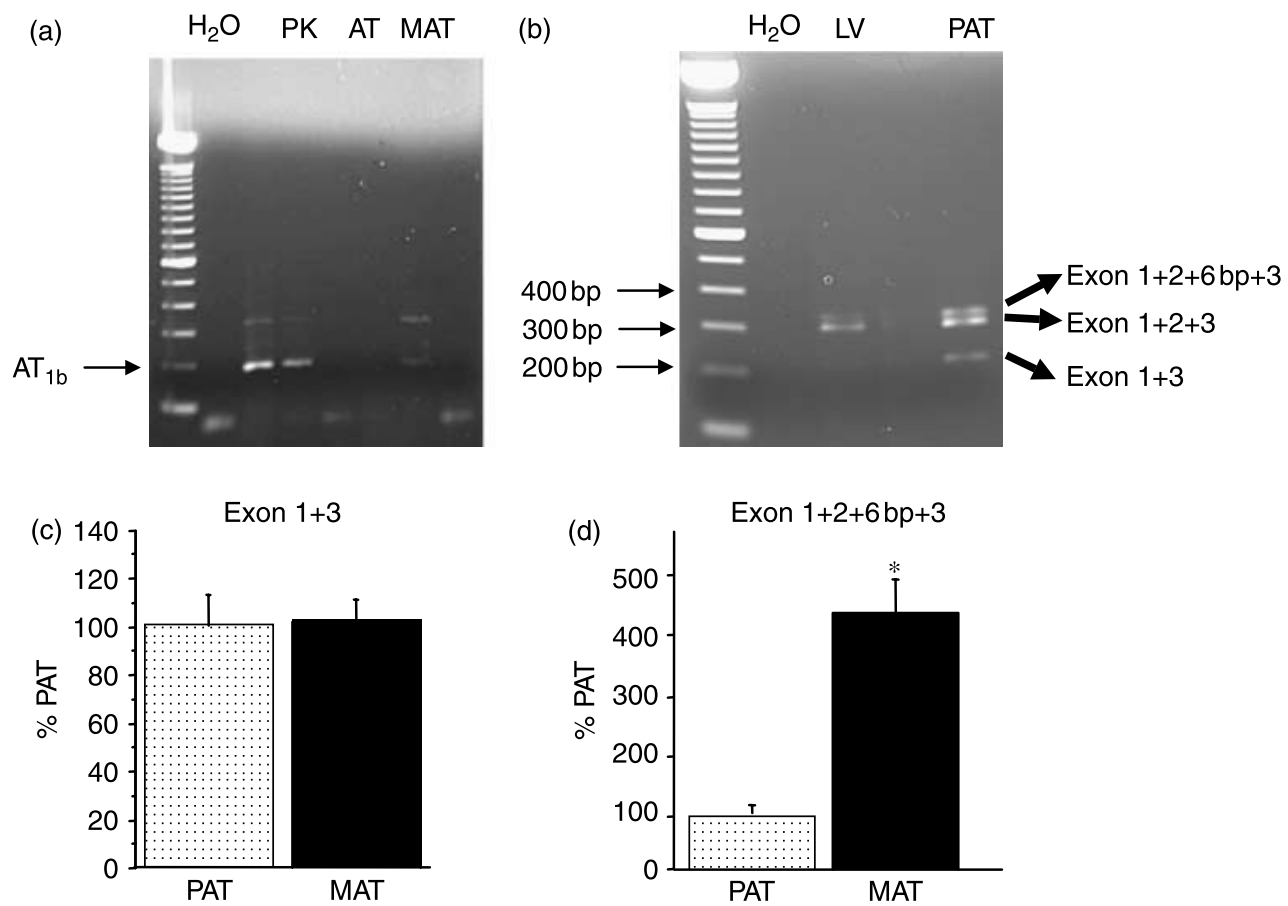

Figure 4 The $\mathrm{AT}_{1 \mathrm{a}}$ receptor isoforms in periaortic adipose tissue. (a) RT-PCR products of the $A T_{1 b}$ receptor in kidney $(\mathrm{K})$, but absence in PAT and MAT. (b) RT-PCR products indicating the existence of three splice variants of the $\mathrm{AT}_{1 \text { a }}$ receptor in adipose tissue. Expression levels in PAT and MAT of (c) Exon $1+3$, and (d) Exon $1+2+$ $6 \mathrm{bp}+3$. Results are normalized to the housekeeping gene $18 \mathrm{~S}$ and are expressed as percentage of the expression level in PAT. $* P<0 \cdot 05$.

tissue surrounding mesenteric arteries can be considered visceral fat, whereas PAT and fat surrounding other blood vessels are not included in this definition. We have compared RAS expression in PAT and MAT. Our characterization of these adipose tissues shows that periaortic fat is brown (BAT) with smaller adipocytes, whereas mesenteric fat is WAT with larger adipocytes. This is in line with previous suggestions (Kortelainen et al. 1993, Matthias et al. 1994, Hausman et al. 2002), although it is the first demonstration of a differential expression of UCP-1 in PAT and MAT. Angiotensinogen expression and release from adipose tissue is well known. In fact, WAT is the most abundant source of angiotensinogen after the liver (Campbell \& Habener 1987, Phillips et al. 1993). Visceral adipose tissue exhibits higher angiotensinogen levels than subcutaneous fat from rodents (Serazin-Leroy et al. 2000) and humans (Giacchetti et al. 2002). Moreover, high levels of angiotensinogen mRNA have been detected in PAT (Campbell \& Habener 1987, Cassis et al. $1988 a, b)$. In the present study, we can show that angiotensinogen expression is similar between white and brown PVATs.

Regarding renin mRNA expression in adipose tissue, there are conflicting results in the literature, which might be related to the species and type of adipose tissue (Engeli et al. 2003 and references therein). In our study, the renin mRNA expression was undetectable in either type of PVAT investigated, which is at variance with previously reported studies for other types of adipose tissues (Engeli et al. 1999, Giacchetti et al. 2002).
Our finding supports the concept that the functional role of RAS in PVAT does not depend on local renin synthesis but rather on renin or prorenin uptake from the circulation.

It is of interest that we detected the expression of the recently identified (pro)renin receptor (Nguyen et al. 2002, Danser et al. 2007) in both MAT and PAT. The presence of this receptor has been reported recently in human subcutaneous (Engeli et al. 2005, Achard et al. 2007) and visceral adipose tissue (Zorad et al. 2006, Achard et al. 2007). In our study, expression of the (pro)renin receptor could be detected in both white and brown PVATs, with higher levels of mRNA expression in periaortic fat.
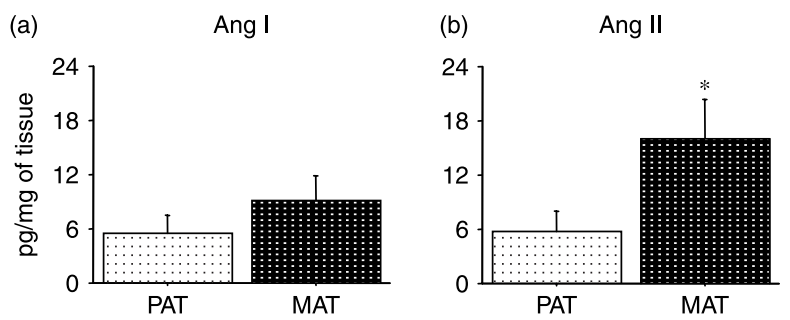

Figure 5 Ang I and Ang II peptide levels in perivascular adipose tissues: periaortic adipose tissue (PAT) and mesenteric adipose tissue (MAT). (a) Ang I and (b) Ang II levels. Results are expressed as $\mathrm{pg} / \mathrm{mg}$ of tissue. $n=6$ for each group. ${ }^{*} P<0 \cdot 05$. 
The expression of angiotensinogen in PVAT highlights the potential role of local periadventitial synthesis of Ang I for the first time. This is confirmed by our detection of high levels of Ang I in both perimesenteric and periaortic fat. The Ang I levels were not different between both types of adipose tissue.

Regarding Ang II, we detected higher levels of this peptide in MAT. Other authors have found a fourfold higher amount of Ang II in rat BAT (Campbell et al. 1993, 1995, Shenoy \& Cassis 1997) compared with WAT (Phillips et al. 1993). The Ang II synthesis in these tissues can be catalyzed by either ACE or chymase. ACE has been detected in WATs (Jonsson et al. 1994, Engeli et al. 1999, Schling et al. 1999, Giacchetti et al. 2002), whereas there are no data in the literature regarding ACE expression in BAT. ACE mRNA was found in subcutaneous and visceral adipose tissue in rodents (Crandall et al. 1992, Pinterova et al. 2000) and humans (Jonsson et al. 1994, Engeli et al. 1999, Giacchetti et al. 2002). Moreover, ACE activity was detected in human preadipocytes (Schling et al. 1999). Expression of $\boldsymbol{\alpha}$-chymase has been described to date only in human adipocytes (Engeli et al. 1999). The fact that expression levels of both ACE and chymase mRNA are higher in MAT than in PAT might explain the higher amount of Ang II levels in this tissue and might result in different treatment effects at the vascular tissue level during treatment with ACE inhibitors. Hence, local suppression of Ang II synthesis in response to ACE inhibition may be limited in PAT, but not in MAT due to its higher amounts of chymase expression.

The ACE homolog ACE2, which generates angiotensin 1-7 from Ang I (Tipnis et al. 2000), has not been previously described in adipose tissue. Here, we show equal expression of ACE2 in both white and brown PVATs.

The angiotensin receptor subtype that is most abundantly expressed in both WAT (Burson et al. 1994, Cassis et al. 1996, Crandall et al. 1999, Adams et al. 2002) and BAT (Cassis et al. 1996) is the $\mathrm{AT}_{1}$ receptor subtype. Cassis et al. (1996) described that WAT contains a higher number of $\mathrm{AT}_{1}$ receptors than BAT. Accordingly, we found that MAT exhibits a higher $\mathrm{AT}_{1}$ receptor expression than PAT. Mice and rats possess two isoforms of the $\mathrm{AT}_{1}$ receptor $\left(\mathrm{AT}_{1 \mathrm{a}}\right.$ and $\mathrm{AT}_{1 \mathrm{~b}}$ ) encoded by two different genes (Sasamura et al. 1992). In PVAT, we detected $\mathrm{AT}_{1 \mathrm{~b}}$ receptor expression only at a very low level. Interestingly, we found three isoforms of the $\mathrm{AT}_{1 \mathrm{a}}$ receptor in both types of adipose tissue. Existence of three variants of this receptor has been recently described in cardiac fibroblasts (Zhang et al. 2004, Cowling et al. 2005). Rat $\mathrm{AT}_{1 \mathrm{a}}$ receptors contain three exons of which exon 1 and exon 2 represent the $5^{\prime}$-untranslated region (Cowling et al. 2005). It was shown that translation of the $\mathrm{AT}_{1 \mathrm{a}}$ receptor is reduced in the presence of exon 2, so that the smallest splice variant appears to be translated more efficiently (Cowling et al. 2005). We observed higher levels of the variant containing exon 2 in MAT compared with PAT, whereas the short variant was expressed in similar amounts.
Expression of $\mathrm{AT}_{2}$ receptors has recently been reported in epididymal adipose tissue from WKY rats (Zorad et al. 2006). Here, we also show $\mathrm{AT}_{2}$ receptor expression in PVAT with a higher level of expression in mesenteric fat.

In conclusion, we show expression of all components of the RAS, except renin, in PVAT of the aorta and mesenteric arteries from WKY rats. Although Ang I peptide levels are similar between PAT and perimesenteric adipose tissues, both $\mathrm{AT}_{1 \mathrm{a}}$ and $\mathrm{AT}_{2}$ receptor levels are higher in MAT. This suggests that, under certain circumstances, perivascular RAS might play a different role depending on the type of surrounding adipose tissue and the type of vascular bed. There are several issues that deserve future investigation. Since adipose tissue is a complex mixture of various cell types (adipocytes, stromal vascular cells, macrophages, etc.) and we have used whole-tissue homogenates, our study does not clarify the cell type where each RAS component is expressed. Another intriguing question relates to the possible physiological role of the perivascular adipose RAS. Due to the contractile, trophic, and pro-inflammatory effects of Ang II, the local production of this peptide in PVAT could have a substantial impact on vascular function and structure and might play an important role in the development of obesityassociated hypertension and vascular remodeling.

\section{Acknowledgements}

Supported by Ministerio de Ciencia y Tecnología (SAF 2005-0518 and SAF 2006-02456), the Bundesministerium für Bildung und Forschung (Nationales Genomforschungsnetz: KGCV1, 01GS0416, NGFN), the German Hypertension Society (Deutsche Hochdruckliga e.V. DHL), Fundación Universitaria San Pablo-CEU, and Society for the Study of Cardiometabolic Health (SESCAMET). B G-P is a fellow from Universidad Complutense. B $\mathrm{M}$ and $\mathrm{A} \mathrm{H}$ are supported by a grant of Ministerio de Educación y Ciencia. The authors declare that there is no conflict of interest that would prejudice the impartiality of this scientific work.

\section{References}

Achard V, Boullu-Ciocca S, Desbriere R, Nguyen G \& Grino M 2007 Renin receptor expression in human adipose tissue. American Journal of Physiology. Regulatory, Integrative and Comparative Physiology 292 274-282.

Adams F, Wiedmer P, Gorzelniak K, Engeli S, Klaus S \& Boschmann M 2002 Age-related changes of renin-angiotensin system genes in white adipose tissue of rats. Hormone and Metabolic Research 34 716-720.

Bolbrinker J, Markovic S, Wehland M, Melenhorst WB, van Goor H \& Kreutz R 2006 Expression and response to angiotensin-converting enzyme inhibition of matrix metalloproteinases 2 and 9 in renal glomerular damage in young transgenic rats with renin-dependent hypertension. Journal of Pharmacology and Experimental Therapeutics 316 8-16.

Boustany CM, Bharadwaj K, Daugherty A, Brown DR, Randall DC \& Cassis LA 2004 Activation of the systemic and adipose renin-angiotensin system in rats with diet-induced obesity and hypertension. American Journal of Physiology. Regulatory, Integrative and Comparative Physiology 287 943-949. 
Burson JM, Aguilera G, Gross KW \& Sigmund CD 1994 Differential expression of angiotensin receptor $1 \mathrm{~A}$ and $1 \mathrm{~B}$ in mouse. American Journal of Physiology. Endocrinology and Metabolism 267 260-267.

Campbell DJ \& Habener JF 1987 Cellular localization of angiotensinogen gene expression in brown adipose tissue and mesentery: quantification of messenger ribonucleic acid abundance using hybridization in situ. Endocrinology 121 1616-1626.

Campbell DJ, Kladis A \& Duncan AM 1993 Nephrectomy, converting enzyme inhibition, and angiotensin peptides. Hypertension 22 513-522.

Campbell DJ, Rong P, Kladis A, Rees B, Ganten D \& Skinner SL 1995 Angiotensin and bradykinin peptides in the TGR(mRen-2)27 rat. Hypertension 25 1014-1020.

Cassis LA, Lynch KR \& Peach MJ 1988a Localization of angiotensinogen messenger RNA in rat aorta. Circulation Research 62 1259-1262.

Cassis LA, Saye J \& Peach MJ $1988 b$ Location and regulation of rat angiotensinogen messenger mRNA. Hypertension 11 591-596.

Cassis LA, Fettinger MJ, Roe AL, Shenoy UR \& Howard G 1996 Characterization and regulation of angiotensin II receptors in rat adipose tissue. Angiotensin receptors in adipose tissue. Advances in Experimental Medicine and Biology 396 39-47.

Cowling RT, Zhang X, Reese VC, Iwata M, Gurantz D, Dillmann WH, Barry H \& Greenberg BH 2005 Effects of cytokine treatment on angiotensin II type $1 \mathrm{~A}$ receptor transcription and splicing in rat cardiac fibroblasts. American Journal of Physiology. Heart and Circulatory Physiology 289 1176-1183.

Crandall DL, Gordon G, Herzlinger HE, Saunders BD, Zolotor RC, Cervoni P \& Kral JG 1992 Transforming growth factor alpha and atrial natriuretic peptide in white adipose tissue depots in rats. European Journal of Clinical Investigation 22 676-680.

Crandall DL, Armellino DC, Busler DE, McHendry-Rinde B \& Kral JG 1999 Angiotensin II receptors in human preadipocytes: role in cell cycle regulation. Endocrinology 140 154-158.

Danser AHJ, Batenburg WW \& van Esch JHM 2007 Prorenin and the (pro)renin receptor - an update. Nephrology, Dialysis, Transplantation 22 1288-1292.

Darimont C, Vassaux G, Ailhaud G \& Negrel R 1994 Differentiation of preadipose cells: paracrine role of prostacyclin upon stimulation of adipose cells by angiotensin-II. Endocrinology 135 2030-2036.

Dubrovska G, Verlohren S, Luft FC \& Gollasch M 2004 Mechanisms of ADRF release from rat aortic adventitial adipose tissue. American Journal of Physiology 286 1107-1113.

Engeli S, Gorzelniak K, Kreutz R, Runkel N, Distler A \& Sharma AM 1999 Co-expression of renin-angiotensin system genes in human adipose tissue. Journal of Hypertension 17 555-560.

Engeli S, Négrel R \& Sharma AM 2000 Physiology and pathophysiology of the adipose tissue renin-angiotensin system. Hypertension 35 1270-1277.

Engeli S, Schling P, Gorzelniak K, Boschmann M, Janke J, Ailhaud G, Teboul M, Massiera F \& Sharma AM 2003 The adipose-tissue renin-angiotensinaldosterone system: role in the metabolic syndrome? International Journal of Biochemistry and Cell Biology 35 807-825.

Engeli S, Bohnke J, Gorzelniak K, Janke J, Schling P, Bader M, Luft FC \& Sharma AM 2005 Weight loss and the renin-angiotensin-aldosterone system. Hypertension 45 356-362.

Frederich RC Jr, Kahn BB, Peach MJ \& Flier JS 1992 Tissue-specific nutritional regulation of angiotensinogen in adipose tissue. Hypertension 19 339-344.

Galvez B, de Castro J, Herold D, Dubrovska G, Arribas S, Gonzalez MC, Aranguez I, Luft FC, Ramos MP, Gollasch M et al. 2006 Perivascular adipose tissue and mesenteric vascular function in spontaneously hypertensive rats. Arteriosclerosis, Thrombosis, and Vascular Biology 26 1297-1302.

Gao YJ, Takemori K, Su LY, An WS, Lu C, Sharma AM \& Lee RM 2006 Perivascular adipose tissue promotes vasoconstriction: the role of superoxide anion. Cardiovascular Research 71 363-373.

Giacchetti G, Faloia E, Mariniello B, Sardu C, Gatti C, Camilloni MA, Guerrieri M \& Mantero F 2002 Overexpression of the renin-angiotensin system in human visceral adipose tissue in normal and overweight subjects. American Journal of Hypertension 15 381-388.
Gorzelniak K, Engeli S, Janke J, Luft FC \& Sharma AM 2002 Hormonal regulation of the human adipose-tissue renin-angiotensin system: relationship to obesity and hypertension. Journal of Hypertension 20 965-973.

Harp JB \& DiGirolamo M 1995 Components of the renin-angiotensin system in adipose tissue: changes with maturation and adipose mass enlargement. Journals of Gerontology. Series A, Biological Sciences and Medical Sciences $\mathbf{5 0} 270-276$.

Hausman DB, DiGirolamo M, Bartness TJ, Hausman GJ \& Martin RJ 2002 The biology of white adipocyte proliferation. Obesity Reviews 2 239-254.

Iwai N \& Inagami T 1992 Identification of two subtypes in the rat type I angiotensin II receptor. FEBS Letters 298 257-260.

Janke J, Engeli S, Gorzelniak K, Luft FC \& Sharma AM 2002 Mature adipocytes inhibit in vitro differentiation of human preadipocytes via angiotensin type 1 receptors. Diabetes 51 1699-1707.

Jonsson JR, Game PA, Head RJ \& Frewin DB 1994 The expression and localisation of the angiotensin-converting enzyme mRNA in human adipose tissue. Blood Pressure 3 72-75.

Kortelainen ML, Pelletier G, Ricquier D \& Bukowiecki LJ 1993 Immunohistochemical detection of human brown adipose tissue uncoupling protein in an autopsy series. Journal of Histochemistry and Cytochemistry $41759-764$

Löhn M, Dubrovska G, Lauterbach B, Luft FC, Gollasch M \& Sharma AM 2002 Periadventitial fat releases a vascular relaxing factor. FASEB Journal 16 $1057-1063$

Märin P, Andersson B, Ottosson M, Olbe L, Chowdhury B, Kvist H, Holm G, Sjöström L \& Björntorp P 1992 The morphology and metabolism of intraabdominal adipose tissue in men. Metabolism 41 $1242-1248$.

Massiera F, Bloch-Faure M, Ceiler D, Murakami K, Fukamizu A, Gasc JM, Quignard-Boulange A, Negrel R, Ailhaud G, Seydoux J et al. 2001 Adipose angiotensinogen is involved in adipose tissue growth and blood pressure regulation. FASEB Journal 15 2727-2729.

Matthias A, Richards SM, Dora KA, Clark MG \& Colquhoun EQ 1994 Characterization of perfused periaortic brown adipose tissue from the rat. Canadian Journal of Physiology and Pharmacology 72 344-352.

Nguyen G, Delarue F, Burcklé C, Bouzhir L, Giller T \& Sraer JD 2002 Pivotal role of the renin/prorenin receptor in angiotensin II production and cellular responses to rennin. Journal of Clinical Investigation 109 1417-1427.

Paul M, Mehr AP \& Kreutz R 2006 Physiology of the renin-angotensin systems. Physiological Reviews 86 747-803.

Phillips MI, Speakman EA \& Kimura B 1993 Levels of angiotensin and molecular biology of the tissue renin angiotensin systems. Regulatory Peptides 43 1-20.

Pinterova L, Krizanova O \& Zorad S 2000 Rat epididymal fat tissue express all components of the renin-angiotensin system. General Physiology and Biophysics 19 329-334.

Rodbell M 1964 Metabolism of isolated fat cells. I. Effects of hormones on glucose metabolism and lipolysis. Journal of Biological Chemistry 239 375-380.

Saint-Marc P, Kozak LP, Ailhaud G, Darimont C \& Negrel R 2001 Angiotensin II as a trophic factor of white adipose tissue: stimulation of adipose cell formation. Endocrinology 142 487-492.

Sasamura H, Hein L, Krieger JE, Pratt RE, Kobilka BK \& Dzau VJ 1992 Cloning, characterization, and expresión of two angiotensin receptor (AT-1) isoforms from the mouse genome. Biochemical and Biophysical Research Communications 185 253-259.

Saye JA, Ragsdale NV, Carey RM \& Peach MJ 1993 Localization of angiotensin peptide-forming enzymes of 3T3-F442A adipocytes. American Journal of Physiology 264 1570-1576.

Schling P, Mallow H, Trindl A \& Löffler G 1999 Evidence for a local renin angiotensin system in primary cultured human preadipocytes. International Journal of Obesity 23 336-341.

Serazin-Leroy V, Morot M, de Mazancourt P \& Giudicelli Y 2000 Androgen regulation and site specificity of angiotensinogen gene expression and secretion in rat adipocytes. American Journal of Physiology. Endocrinology and Metabolism 279 1398-1405.

Shenoy U \& Cassis L 1997 Characterization of renin activity in brown adipose tissue. American Journal of Physiology. Cell Physiology 272 989-999. 
Soltis EE \& Cassis LA 1991 Influence of perivascular adipose tissue on rat aortic smooth muscle responsiveness. Clinical and Experimental Hypertension 275 681-692.

Tipnis SR, Hooper NM, Hyde R, Karran E, Christie G \& Turner AJ 2000 A human homolog of angiotensin-converting enzyme: cloning and functional expression of a captopril-insensitive carboxypeptidase. Journal of Biological Chemistry 275 33238-33243.

Verlohren S, Dubrovska G, Tsang S-Y, Essine K, Luft FC, Huang Y \& Gollasch M 2004 Visceral periadventitial adipose tissue regulates arterial tone of mesenteric arteries. Hypertension 44 271-276.

Wendt N, Schulz A, Siegel AK, Weiss J, Wehland M, Sietmann A, Kossmehl P, Grimm D, Stoll M \& Kreutz R 2007 Rat chromosome 19 transfer from SHR ameliorates hypertension, salt-sensitivity, cardiovascular and renal organ damage in salt-sensitive Dahl rats. Journal of Hypertension 25 95-102.
Zhang Y, Ji H, Fabucci ME, Falconetti C, Zheng W \& Sandberg K 2004 Translational control of the rat angiotensin type 1 a receptor by alternative splicing. Gene 341 93-100.

Zorad S, Dou J, Benicky J, Hutanu D, Tybitanclova K, Zhou J \& Saavedra JM 2006 Long-term angiotensin II AT1 receptor inhibition produces adipose tissue hypotrophy accompanied by increased expression of adiponectin and PPAR $\gamma$. European Journal of Pharmacology 552 112-122.

Received in final form 28 November 2007

Accepted 9 January 2008

Made available online as an Accepted Preprint 9 January 2008 